\title{
The distribution of the outer gas vesicle protein, GvpC, on the Anabaena gas vesicle, and its ratio to GvpA
}

\author{
B. E. E. BuchHolz, P. K. HaYes and A. E. Walsby* \\ Department of Botany, University of Bristol, Woodland Road, Bristol BS8 1UG, UK
}

(Received 23 December 1992; revised 8 April 1993; accepted 19 April 1993)

\begin{abstract}
Previous studies have shown that gas vesicles isolated from the cyanobacterium Anabaena flos-aquae contain two types of protein, GvpA, a small hydrophobic protein that forms the main ribbed structure, and GvpC, a protein comprising five repeats of a 33-amino-acid-residue motif, which is located on the outer surface of the GvpA shell. GvpC was shown to increase the critical collapse pressure of the gas vesicles; it was thought to do this by forming a series of molecular ties that bind the ribs together. We now show that antibodies raised against GvpC label both the central cylinders and the conical end caps of native gas vesicles but fail to bind to gas vesicles that have been stripped of GvpC. The molar ratio of GvpA to GvC has been calculated from amino acid analyses of gas vesicle hydrolysates by reference to the abundance of amino acids that occur predominantly or exclusively in one protein or the other; the molar ratio was found to be $25: 1$ in freshly isolated gas vesicles and 23:1 in gas vesicles saturated with GvpC. We have considered three ways in which the 33-residue repeats of GvpC might interact with the crystallographic unit cell of GvpA molecules in the ribs. The Anabaena $\mathrm{GvpC}$ will bind to and restore the strength of gas vesicles isolated from Aphanizomenon and Microcystis that lack their native GvpC.
\end{abstract}

\section{Introduction}

Gas vesicles are stable gas-filled structures which provide buoyancy in a wide variety of planktonic prokaryotes. The gas vesicle is formed from a rigid shell of protein enclosing a hollow space, which fills with gases by diffusion. In cyanobacteria gas vesicles are cylindrical with conical end caps (Bowen \& Jensen, 1965; Jost, 1965). Both the central cylinder and end caps are made up of ribs orientated perpendicular to the long axis of the cylinder (Jost, 1965; Jost \& Jones, 1970). In order to maintain the gas-filled space that actually provides buoyancy a gas vesicle must withstand the combination of turgor pressure and hydrostatic pressure experienced in the natural habitat (Walsby, 1972). If the gas vesicle is exposed to a pressure that exceeds a certain value, known as the critical pressure $\left(p_{c}\right)$, it collapses irreversibly (Walsby, 1971).

In Anabaena flos-aquae GvpA, a small hydrophobic protein of $M_{\mathrm{r}} 7397$, forms the main ribbed structure (Hayes et al., 1986); GvpC, a larger hydrophilic protein of $M_{\mathrm{r}} 21985$, is a minor component (Hayes et al., 1988). GvpC can be removed from gas vesicles of Anabaena

\footnotetext{
*Author for correspondence.
}

Abbreviations: anti-GV antibodies, antibodies raised against entire gas vesicles; PSOD, pressure-sensitive optical density. flos-aquae by rinsing them with solutions of SDS (Walsby \& Hayes, 1988) or $6 \mathrm{~m}$-urea (Hayes et al., 1992). The rinsed structures are not collapsed by this treatment and it has been concluded that GvpC must be located on the outside of the shell formed by GvpA (Walsby \& Hayes, 1988). Removal of GvpC does cause weakening of the gas vesicle, however, and it was suggested that the function of this protein might be to strengthen the structure (Walsby \& Hayes, 1988). This has been proved by Hayes et al. (1992), who demonstrated that when GvpC was reattached to gas vesicles that had been stripped of their native GvpC, their strength was restored.

Hayes et al. (1988) suggested that GvpC might stiffen gas vesicles against buckling (see Walsby, 1991) by forming ties that cross the GvpA ribs and hold them together. The GvpC sequence contains five highly conserved 33-amino-acid-residue repeats, which are predicted to be mainly in an $\alpha$-helical conformation. An $\alpha$-helix of 33 amino acids would have a length of $5 \mathrm{~nm}$, which would be sufficient to span a rib $4.6 \mathrm{~nm}$ wide (Hayes et al., 1988). A single 33-amino-acid helix might contact a set of several GvpA molecules across the rib; five helical repeats of the same sequence might cross five ribs and form identical contacts with five sets of GvpA molecules. The molar ratio of GvpA to GvpC would then be expected to be an integer multiple of $5: 1$; for 
example, if there were $4 \mathrm{GvpAs}$ in each set the molar ratio would be $(4 \times 5): 1$ or $20: 1$.

Hayes et al. (1988) pointed out that, with knowledge of the precise amino acid composition of each protein, obtained from their amino acid sequences, the relative proportions of the two proteins in Anabaena gas vesicles could be determined by analysing their amino acid composition. In particular, the proportions could be determined by measuring the fraction of the total protein formed by certain amino acids that occurred exclusively in either GvpC (phenylalanine, methionine and histidine) or GvpA (proline and tryptophan). In this way the ratio of GvpA: GvpC was calculated from the abundance of phenylalanine to be $33 \cdot 1$, from the abundance of proline to be 35.0 (Hayes et al., 1988), and from the abundance of methionine to be 30.3 (Walsby \& Hayes, 1988).

In attempting to relate these ratios to the way in which molecules of GvpA and GvpC interact with one another in the gas vesicle we have to take account of three factors. The first is that GvpC might have been absent from part of the structure, such as the end cones. The distribution of GvpC over the outer surface of the gas vesicle has not been previously investigated. Powell et al. (1991) showed that polyclonal antibodies raised against the N-terminal sequence of GvpA (anti-GvpA antibodies) labelled the conical ends of Anabaena gas vesicles only after GvpC had been removed with SDS; this seemed to suggest, though did not prove, that GvpC was present on the end caps, obscuring GvpA. We have now used gold-labelled anti-GvpC antibodies to show by direct means that GvpC is distributed over the entire outer surface of the gas vesicle.

The second factor is that some GvpC might have been lost during the isolation of gas vesicles. It has already been demonstrated that the mobile band of gas vesicle protein (now identified as GvpC) can be lost from isolated gas vesicles on storage (Walker \& Walsby, 1983). We have now reinvestigated the ratio of GvpA to GvpC by quantitative amino acid analyses of Anabaena gas vesicles that had been isolated using methods that minimize or prevent GvpC loss (Powell et al., 1991).

The third factor is that not all of the possible GvpA sites in native gas vesicles may have been occupied. We have attempted to address this possibility by analysing the ratio in gas vesicles in which all of the available sites have been saturated by rebinding with an excess of 'recombinant GvpC'-GvpC produced in Escherichia coli by expression of the recombinant $g v p C$ gene from Anabaena (Hayes et al., 1992). We discuss how the observed ratio of GvpA:GvpC might be generated by the way in which the two proteins interact with one another in the gas vesicle.

It is not definitely known whether GvpC or its counterpart is present in gas vesicles of all cyanobacteria
(Damerval et al., 1989). In the gas vesicles of Pseudanabaena sp. only GvpA has been found (Damerval et al., 1991). Moreover, Damerval et al. (1989) showed that all the gas-vacuolate cyanobacteria they investigated contained a gene homologous to gvp $A$ from Calothrix sp., but only half of them contained sequences homologous to Calothrix gvpC. It is possible, however, that the nucleotide sequence of the gene that encodes the second protein may have diverged to the extent that it cannot be detected by DNA:DNA hybridization. Gas vesicles isolated from seven genera of cyanobacteria have been shown to contain both GvpA and GvpC (Hayes et al., 1986; Damerval et al., 1987; Hayes et al., 1988; Griffiths et al., 1992), though the sequences of GvpC were found to be less conserved than those of GvpA (Griffiths et al., 1992). This raises the question of whether the different sequences are needed to permit the mutual interactions between the two proteins in different cyanobacteria. We have now demonstrated that the Anabaena GvpC is able to bind to and restrengthen the gas vesicles of other species that have been stripped of their native GvpCs.

\section{Methods}

Strains and growth conditions. Anabaena flos-aquae CCAP 1430/13f (Walsby, 1977) and Aphanizomenon flos-aquae CCAP 1401/1 were grown in medium B-N (Armstrong et al., 1983), and Microcystis sp. CCAP 1450/13 was grown in BG 11 medium of Rippka et al. (1979), at $20^{\circ} \mathrm{C}$ under constant illumination with cool white fluorescent light of photon irradiance $30 \mu \mathrm{mol} \mathrm{m}{ }^{-2} \mathrm{~s}^{-1}$. E. coli $\mathrm{N} 4830-1$ carrying the Anabaena gvpC gene was grown at $37^{\circ} \mathrm{C}$ for $16 \mathrm{~h}$ in L-broth containing $100 \mu \mathrm{g}$ ampicillin $\mathrm{ml}^{-1}$ (Hayes et al., 1992).

Gas vesicle preparations. Cells of Microcystis sp. were lysed with lysozyme using the conditions described by Griffiths et al. (1992), and those of Anabaena and Aphanizomenon were lysed by osmotic shrinkage in $0.7 \mathrm{M}$-sucrose. Intact gas vesicles were isolated and purified as described by Walsby \& Hayes (1988), except that contaminating thylakoids were separated by centrifugation from the layers of floating gas vesicles, rather than by rinsing with SDS. The purified gas vesicles were stored in $6.3 \mathrm{~mm}-\mathrm{NH}_{4} \mathrm{HCO}_{3}$ containing $5 \mathrm{~mm}-\mathrm{NaCN}$ to prevent bacterial contamination and degradation (Powell et al., 1991). The concentration of total gas vesicle proteins in the Anabaena gas vesicle preparations was determined by measurements of the pressure-sensitive optical density (PSOD) at a wavelength of $500 \mathrm{~nm}$; a suspension containing $1 \mathrm{mg}$ protein $\mathrm{ml}^{-1}$ gives a PSOD of $20.9 \mathrm{~cm}^{-1}$ (Walsby \& Armstrong, 1979).

Preparation of recombinant GvpC and antibody production. Recombinant $A$. flos-aquae $\mathrm{GvpC}$ was prepared from E. coli $\mathrm{N} 4830-1$ as described previously (Hayes et al., 1992), or from E. coli cells in $100 \mathrm{ml}$ cultures grown to an optical density (at $750 \mathrm{~nm}$ in $1 \mathrm{~cm}$ cuvettes) of 1.5 to 2.0 and then resuspended in $15 \mathrm{ml}$ lysis buffer containing $150 \mathrm{mM}-$ $\mathrm{NaCl}, 1 \%$ (v/v) NP-40, 50 mm-Tris pH 8 (Harlow \& Lane, 1988, p. $447)$ and subjected to sonic cavitation $(4 \times 30 \mathrm{~s}$, Soniprobe, Dawes Instruments). GvpC was dissolved in buffered $6 \mathrm{M}$-urea at a concentration of about $8 \mu \mathrm{g} \mu \mathrm{l}^{-1}$. To raise antibodies GvpC was further purified using a protocol of Harlow \& Lane (1988, pp. 61-70). GvpC was separated from other proteins by SDS-PAGE $(12 \%, w / v$, acrylamide; Laemmli, 1970). The GvpC bands were excised and the gel slices lyophilized. The dried gel slices were ground into a fine powder and resuspended in sterile water. This preparation containing $420 \mu \mathrm{g}$ of 


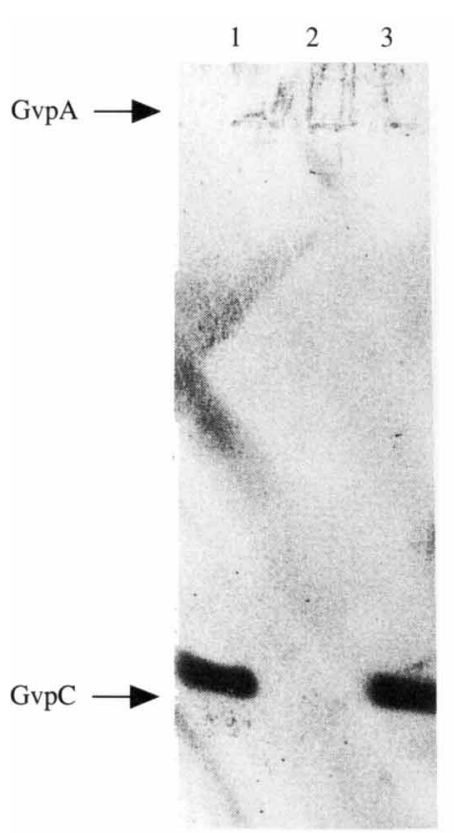

(a)

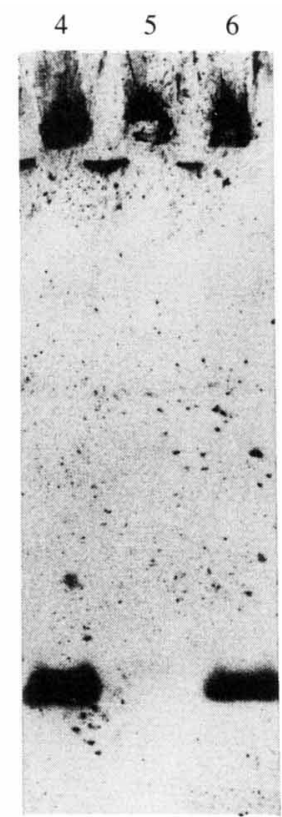

(b)

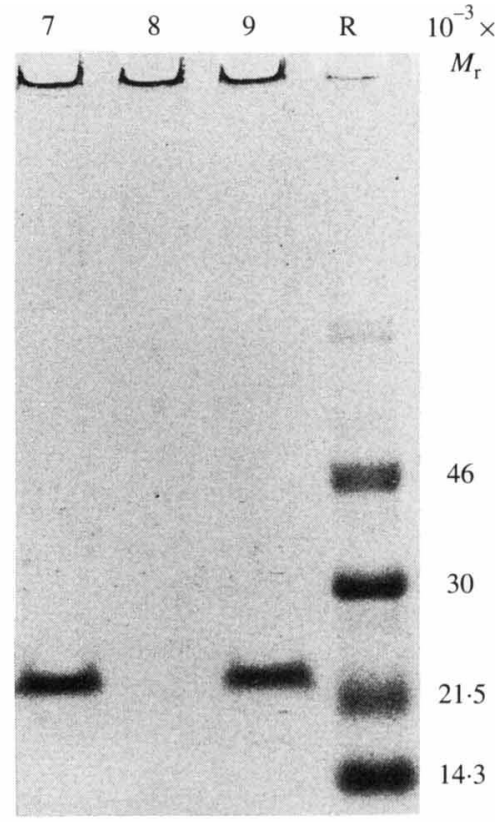

(c)

Fig. 1. SDS-PAGE and immunoblotting of Anabaena flos-aquae gas vesicle preparations. Lanes 1, 4, 7, purified gas vesicles containing GvpA and GvpC; lanes 2, 5, 8, gas vesicles stripped of GvpC; lanes 3, 6, 9, stripped gas vesicles saturated with recombinant GvpC. $\mathrm{R}$, 'Rainbow' size markers, with $M_{\mathrm{r}}$ values. (a) Blot probed with anti-GvpC antibodies; (b) blot probed with anti-GV antibodies; (c) gel stained with Coomassie blue.

recombinant Anabaena GvpC was injected into a rabbit from which the immune serum was subsequently collected after four booster inoculations (anti-GvpC antibodies). A first bleed was taken before the immunization began, to give a preimmune control. Rabbit antibodies raised against entire purified gas vesicles (anti-GV antibodies) were those used previously by Walker et al. (1984) and Powell et al. (1991). The specificity of the sera was tested by immunoblotting. The amounts of GvpC used were estimated by comparison with standard protein solutions separated by SDS-PAGE.

Saturation of gas vesicles with recombinant $G v p C$. To remove GvpC, samples of intact gas vesicles were suspended in $6 \mathrm{M}$-urea (or $8 \mathrm{M}$-urea for gas vesicles from microcystis $\mathrm{sp}$.) buffered with $0 \cdot 1 \mathrm{M}-\mathrm{Tris} / \mathrm{HCl}$ (pH 8.5). The stripped gas vesicles were recovered by centrifugally accelerated flotation and rinsed three times with $6.3 \mathrm{mM}-\mathrm{NH}_{4} \mathrm{HCO}_{3}$ (Hayes et al., 1992). The stripped gas vesicles were saturated with recombinant Anabaena GvpC (Hayes et al., 1992) by mixing $420 \mu \mathrm{g}$ urea-treated gas vesicles with $640 \mu \mathrm{g}$ recombinant $\mathrm{GvpC}$ in $1 \mathrm{ml} 6 \mathrm{M}$ buffered urea. GvpC was allowed to bind to the stripped gas vesicles in gradually decreasing urea concentrations by dialysing against three 5 litre volumes of $6.3 \mathrm{~mm}-\mathrm{NH}_{4} \mathrm{HCO}_{3}$ at $4{ }^{\circ} \mathrm{C}$ for a total time of about $72 \mathrm{~h}$. Intact gas vesicles were recovered by centrifugally accelerated flotation. Excess unbound recombinant $\mathrm{GvpC}$ was removed by rinsing three times with $6.3 \mathrm{~mm}-\mathrm{NH}_{4} \mathrm{HCO}_{3}$.

Amino acid analysis. Gas vesicle samples were hydrolysed under vacuum for $24 \mathrm{~h}$ at $110^{\circ} \mathrm{C}$ with $6 \mathrm{M}-\mathrm{HCl}$ containing $0.1 \%$ phenol (Thompson \& Sanger, 1963). Quantitative amino acid analyses were performed using either a modified Waters Pico-Tag HPLC system or by reverse-phase high-performance liquid chromatography (Flynn, 1988).

Immunoblotting. Anabaena gas vesicle suspensions were mixed with loading buffer containing $5 \%(\mathrm{w} / \mathrm{v}) \mathrm{SDS}, 10 \%(\mathrm{w} / \mathrm{v})$ glycerol, $5 \mathrm{~mm}-$ EDTA, 2 mM-Tris, $0.01 \%(\mathrm{w} / \mathrm{v})$ bromophenol blue and $0.01 \%(\mathrm{w} / \mathrm{v})$ xylene cyanol $\mathrm{fr}$. Gas vesicle samples containing $20 \mu \mathrm{g}$ gas vesicle protein (estimated by PSOD) were separated by SDS-PAGE. After gel electrophoresis the proteins were transferred from the gel to a nitrocellulose membrane (Hybond-C Extra, Amersham) using a semidry electroblotter (Sartorius). For blotting and protein detection the instructions of the manufacturer were followed.

Immunogold labelling of gas vesicles. For the immunogold labelling of Anabaena gas vesicles, a method described by Hayat (1989, p. 350) was adopted. Samples of gas vesicles were diluted with distilled water and drops of this suspension were dried down onto 400-mesh Formvarcoated copper grids. The grids were incubated face down for $15 \mathrm{~min}$ on drops of antiserum diluted between 10 - and 100 -fold. They were then drained with a filter paper strip, washed six times on drops of PBS (phosphate-buffered saline, $\mathrm{pH} 7 \cdot 3$, Oxoid) and then floated for $30 \mathrm{~min}$ on a drop of 100 -fold diluted $10 \mathrm{~nm}$ gold spheres conjugated to Protein A (Sigma). The grids were drained and washed as described above with two final washes on drops of distilled water. Sera and Protein A-gold conjugate were diluted in PBS containing $1 \%(\mathrm{w} / \mathrm{v})$ bovine serum albumin (Sigma) and $0.1 \%(\mathrm{w} / \mathrm{v})$ gelatin (USP 60 Bloom, Fluka). All solutions were filtered before use $(0.2 \mu \mathrm{m}$ pore size, Sigma). The preparations were then shadowed with platinum/carbon at an angle of $45^{\circ}$ for $10 \mathrm{~s}(2 \mathrm{kV}, 75 \mathrm{~mA})$ in an Edwards $12 \mathrm{E} 6 / 178$ shadowing unit fitted with a Cressington EH5 electron gun, connected to a Cressington EB602 PC power supply (Hayes \& Walsby, 1986). Specimens were examined in a Jeol transmission electron microscope. The distribution of gold-labelling over the gas vesicle surface was determined by comparing the number of gold particles per unit area for cones, cylinders and entire gas vesicles. Counts were made only on entire, unfolded gas vesicles that were well separated from neighbouring ones. For each antibody, gold particles on 14-30 such gas vesicles were counted, though similar distributions were seen on many others. The background labelling was determined by counting gold particles per unit area outside the gas vesicles.

Critical pressure of the gas vesicles. The critical pressure distributions of isolated gas vesicles were determined from the turbidity change 

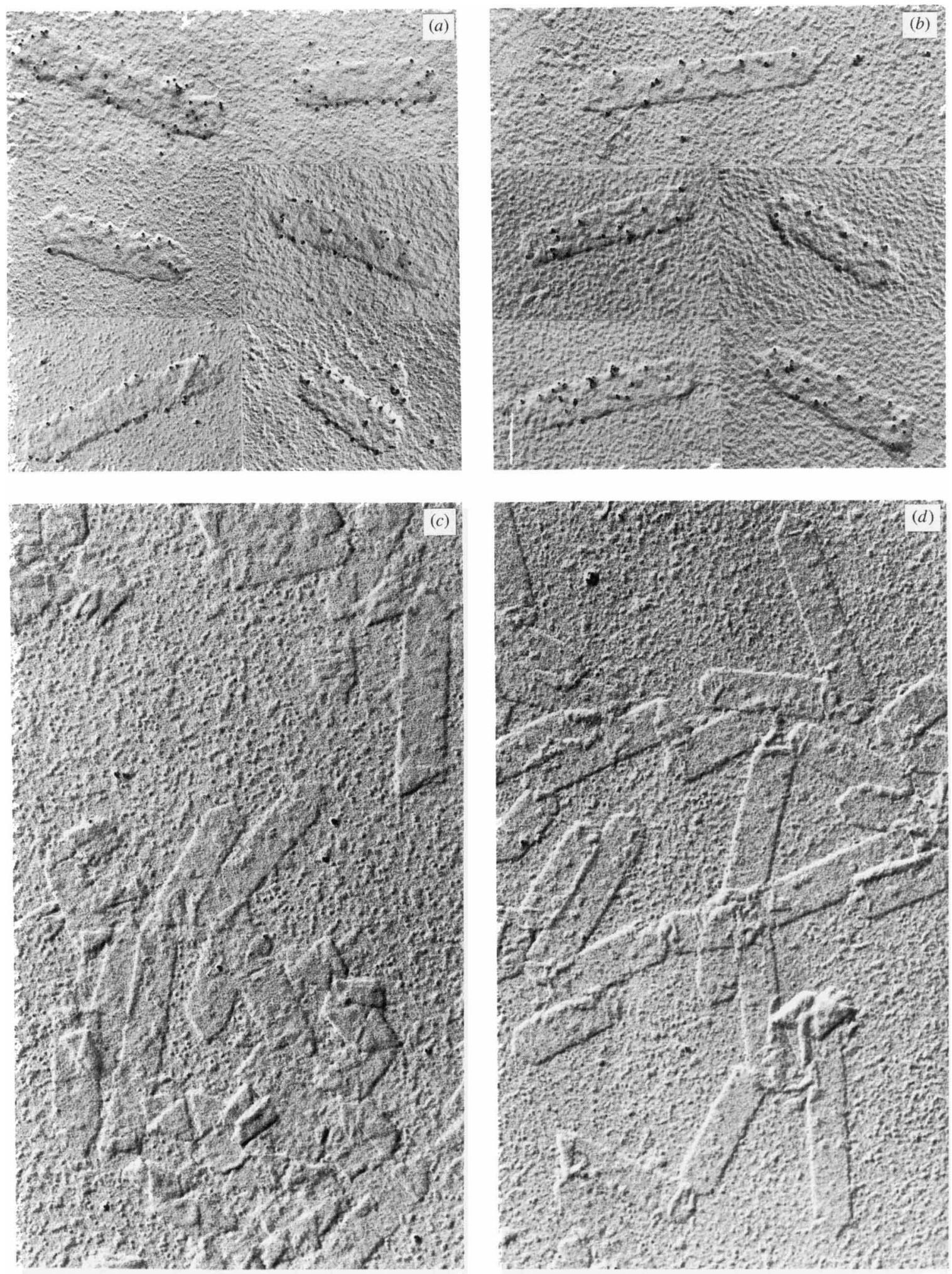

Fig. 2. Immunogold localization of GvpC in the wall of Anabaena flos-aquae gas vesicles. (a) Native gas vesicles probed with anti-GvpC antibody; $(b)$ stripped gas vesicles saturated with recombinant GvpC probed with anti-GvpC antibodies; $(c)$ stripped gas vesicles probed with anti-GvpC antibody; $(d)$ native gas vesicles probed with preimmune serum. 

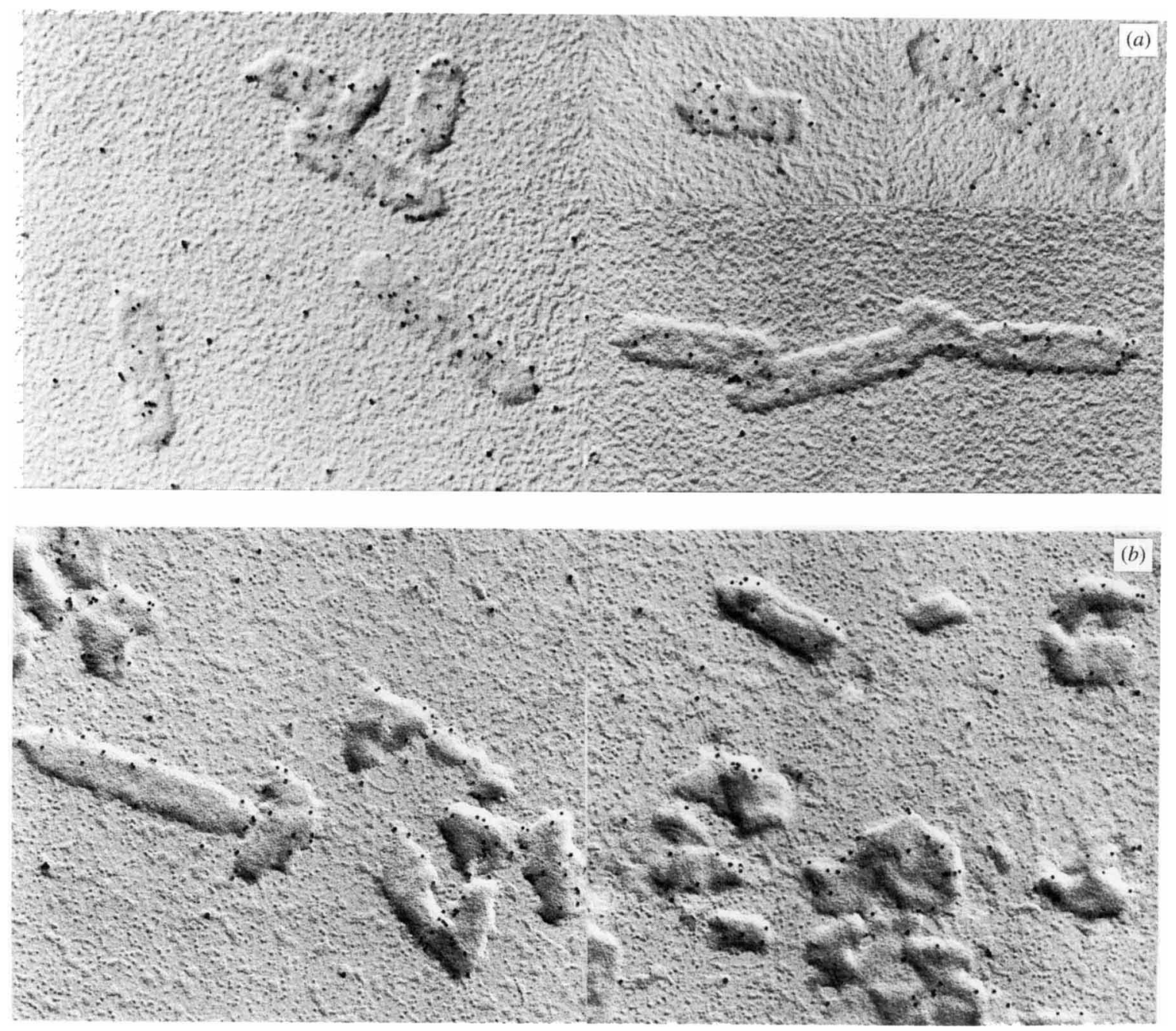

Fig. 3. Immunogold labelling with polyclonal antibodies raised against entire gas vesicles. Anti-GV antibodies became attached to all parts of native gas vesicles $(a)$ and of gas vesicles that had been stripped of GvpC $(b)$.

accompanying gas vesicle collapse (Walsby, 1980), measured in a pressure nephelometer. Replicate measurements were made on gas vesicles suspended in solutions of $5 \mathrm{mM}-\mathrm{K}_{2} \mathrm{HPO}_{4}$ and the mean critical pressures were calculated by the method of Walsby \& Bleything (1988).

\section{Results}

\section{GvpC localization}

The specificity of the anti-GvpC and anti-GV antibodies was confirmed by immunoblotting (Fig. 1). The antiGvpC antibodies bound specifically to GvpC, which runs as a mobile band of $M_{\mathrm{r}} 22000$ in SDS-PAGE (Fig. $1 a$, lanes 1 and 3). Polyclonal antibodies raised against entire gas vesicles (anti-GV antibodies) bound to both the mobile GvpC band and to GvpA, which remains undissolved as particulate matter in the wells of SDS electrophoresis gels (Fig. 1b, lanes 4, 5 and 6).

Gold particles became attached to all parts of the gas vesicles that had been challenged with the anti-GvpC antibody, both in native samples and in samples that had been saturated with recombinant GvpC (Fig. 2a,b). Gold labelling occurred on the central cylinder and the conical end caps. There was no significant difference in the number of gold particles bound by native gas vesicles $\left(265 \pm 115\right.$ particles $\left.\mu \mathrm{m}^{-2}\right)$; and by gas vesicles that had been saturated with recombinant GvpC $(222 \pm 77$ particles $\mu \mathrm{m}^{-2}$ ); background labelling was negligible $\left(5 \pm 3\right.$ particles $\left.\mu \mathrm{m}^{-2}\right)$. The anti-GvpC antibodies did not label gas vesicles that had been treated with urea to remove GvpC (Fig. 2c) and no gold-labelling was observed when preimmune serum was used (Fig. $2 d$ ). The anti-GV antibody labelled both native gas vesicles and gas vesicles stripped of their GvpC (Fig. 3a,b); native gas vesicles bound $307 \pm 128$ particles $\mu \mathrm{m}^{-2}$ with an average background labelling of $11 \pm 5$ particles $\mu \mathrm{m}^{-2}$. A similar labelling pattern was observed by Powell et al. (1991) using the anti-GV antibody but a different labelling technique. It was noted that gas vesicles lacking 
GvpC (Figs $2 c$ and $3 b$ ) showed a greater tendency to fold when they were dried onto grids, than did native gas vesicles that were stiffened by GvpC (Figs $2 d$ and $3 a$ ).

\section{The concentration of GvpC on cylinders and end caps}

We have attempted to determine from the distribution of anti-GvpC antibodies whether GvpC is uniformly distributed over the surface of the gas vesicle.

The middle sections of gas vesicles had a somewhat lower density of labelling with anti-GvpC antibodies (gold particles per unit area) than the end caps: on the gas vesicles with native GvpC the labelling density on the collapsed cylinders was $238 \pm 108 \mu^{-2}$, which was $68 \%$ of that on the cones, $351 \pm 259 \mu^{-2}$; on the cylinders of the gas vesicles saturated with recombinant GvpC the labelling density was $198 \pm 126 \mu \mathrm{m}^{-2}$, which was $65 \%$ of the value on the cones, $309 \pm 190 \mu \mathrm{m}^{-2}$. In some of the electron micrographs (Fig. 2) the cylindrical mid-sections of the gas vesicles appear to be more highly labelled at the edges than in the central regions. A possible explanation for this might be that along the broken edges the GvpC molecules were distorted in such a way as to expose more epitopes that were recognized by the antiGvpC antibodies. The cones might be more highly labelled because they contain a higher ratio of edge to area than the cylinders. In summary, the areal concentration of GvpC is of the same order of magnitude on the cones and cylinders but we do not know if it is identical.

\section{The GvpA to GvpC ratio calculated from amino acid analyses}

The relative amounts of GvpA and GvpC in gas vesicles were calculated from amino acid analyses (Hayes et al., 1988). The amino acid composition of GvpA and GvpC deduced from the amino acid sequence of GvpA (Hayes et al., 1986) and GvpC (Hayes et al., 1988) shows that phenylalanine is only present in GvpC. The absence of phenylalanine in amino acid analysis of gas vesicles rinsed in $6 \mathrm{M}$-urea to remove their GvpC (Table 1) confirms the efficacy of the removal process. The amino acid composition of the acid hydrolysate of gas vesicles stripped of their GvpC was compared with the amino acid composition of GvpA calculated from sequence data (Table 1). As noted previously (Walker \& Walsby, 1983) some of the amino acids are over- or underrepresented in the acid hydrolysates (Table 1). The relative amounts of glycine, threonine, alanine, tyrosine, valine, isoleucine and leucine were within $\pm 10 \%$ of the values expected from the sequence; the amounts of these amino acids in the amino acid hydrolysates, relative to phenylalanine, were used to calculate the GvpA to GvpC ratio in gas vesicles. The ratio of GvpA to GvpC was
Table 1. Amino acid composition of Anabaena flosaquae gas vesicles stripped of GvpC

\begin{tabular}{|c|c|c|c|}
\hline \multirow[b]{2}{*}{$\begin{array}{l}\text { Amino } \\
\text { acid }\end{array}$} & \multicolumn{2}{|c|}{$\begin{array}{c}\text { Composition } \\
\text { (mol per } 100 \mathrm{~mol})\end{array}$} & \multirow[b]{2}{*}{$\begin{array}{l}\text { Percentage } \\
\text { over-/under- } \\
\text { estimation* }\end{array}$} \\
\hline & $\begin{array}{c}\text { Measured } \\
\text { in acid } \\
\text { hydrolysate }\end{array}$ & $\begin{array}{l}\text { Calculated } \\
\text { from GvpA } \\
\text { sequence }\end{array}$ & \\
\hline$A s p+A s n$ & $6 \cdot 5$ & $5 \cdot 7$ & $+13 \cdot 3$ \\
\hline $\mathrm{Glu}+\mathrm{Gln}$ & $11 \cdot 3$ & $10 \cdot 0$ & $+13 \cdot 1$ \\
\hline Ser & $8 \cdot 4$ & $10 \cdot 0$ & $-15 \cdot 6$ \\
\hline His & - & 0 & \\
\hline Gly & $4 \cdot 7$ & $4 \cdot 3$ & $+9 \cdot 4$ \\
\hline Thr & $4 \cdot 4$ & $4 \cdot 3$ & +3.4 \\
\hline Arg & $5 \cdot 2$ & $4 \cdot 3$ & +20.7 \\
\hline Ala & $15 \cdot 4$ & $15 \cdot 7$ & $-2 \cdot 2$ \\
\hline Tyr & $2 \cdot 7$ & $2 \cdot 9$ & -6.6 \\
\hline Met & - & 0 & \\
\hline Val & $14 \cdot 8$ & $14 \cdot 3$ & $+3 \cdot 8$ \\
\hline $\operatorname{Trp}$ & ND & $1 \cdot 4$ & \\
\hline Phe & - & 0 & \\
\hline Ile & $11 \cdot 1$ & $11 \cdot 4$ & $-2 \cdot 4$ \\
\hline Leu & $9 \cdot 9$ & $10 \cdot 0$ & $-1 \cdot 1$ \\
\hline Lys & $5 \cdot 5$ & $4 \cdot 3$ & $+28 \cdot 7$ \\
\hline Pro & ND & 1.4 & \\
\hline Cys & ND & 0 & \\
\hline
\end{tabular}

- , Below the limit of detection; ND, not determined.

* Calculated from the original data; figures shown in columns 2 and 3 are rounded to one decimal place.

calculated for native gas vesicles and for gas vesicles that had been stripped and then saturated with recombinant GvpC (Table 2); a detailed description of the calculation is given in the footnote of Table 2. For gas vesicles stripped and then saturated with recombinant $\mathrm{GvpC}$ the calculated molar ratio was $22 \cdot 7: 1(\mathrm{SD}=1 \cdot 38)$, and for native gas vesicles the molar ratio was $24 \cdot 9: 1(\mathrm{SD}=1 \cdot 25)$. In a separate experiment where only tyrosine, glycine and phenylalanine were analysed in the acid hydrolysates the molar ratio was found to be $25: 1$ for both native gas vesicles and stripped gas vesicles saturated with recombinant GvpC. In all of these calculations it is assumed that GvpA and GvpC are the only components of the gas vesicle. At present there is no direct evidence of any other component. In Calothrix sp. there is a gene, gvpD, that encodes a protein that differs in a few residues from GvpA (Tandeau de Marsac \& Houmard, 1993); if the product of such a gene were to form, say, $10 \%$ of the Anabaena gas vesicle it would make little difference to the ratios calculated above.

\section{Effect of GvpC on critical pressure distribution of gas vesicles}

An analysis was made of the effects of GvpC on the critical pressure distributions of gas vesicles. The gas vesicles isolated from Anabaena flos-aquae (containing native GvpC) had a mean critical pressure $\left(p_{c}\right)$ of 
Table 2. The molar GvpA/GvpC ratio calculated from phenylalanine content of native Anabaena gas vesicles and of Anabaena gas vesicles stripped of native GvpC and then saturated with recombinant GvpC

Numbers are means of three measurements (with standard deviations shown in parentheses).

\begin{tabular}{|c|c|c|c|c|c|c|c|c|}
\hline \multirow[b]{2}{*}{$\begin{array}{l}\text { Amino } \\
\text { acid } \\
\text { analysed }\end{array}$} & \multirow[b]{2}{*}{$\begin{array}{c}\text { GvpA* } \\
\text { (residues } \\
\text { per } \\
\text { molecule) }\end{array}$} & \multirow[b]{2}{*}{$\begin{array}{c}\text { GvpC } † \\
\text { (residues } \\
\text { per } \\
\text { molecule) }\end{array}$} & \multicolumn{3}{|c|}{ Native gas vesicles } & \multicolumn{3}{|c|}{ Reconstituted gas vesicles } \\
\hline & & & $\begin{array}{c}\text { Analysis } \ddagger \\
\text { (mol residue } \\
\text { per } \\
\text { mol Phe) }\end{array}$ & $\begin{array}{c}\text { GvpA§ } \\
\text { (mol GvpA } \\
\text { per } \\
\text { mol Phe) }\end{array}$ & $\begin{array}{c}\text { Ratio\| } \\
\text { (mol GvpA } \\
\text { per } \\
\text { mol GvpC) }\end{array}$ & $\begin{array}{c}\text { Analysis } \ddagger \\
\text { (mol residue } \\
\text { per } \\
\text { mol Phe) }\end{array}$ & $\begin{array}{c}\text { GvpA } \S \\
\text { (mol GvpA } \\
\text { per } \\
\text { mol Phe) }\end{array}$ & $\begin{array}{c}\text { Ratio } \| \\
\text { (mol GvpA } \\
\text { per } \\
\text { mol GvpC) }\end{array}$ \\
\hline Gly & 3 & 1 & $7.0(0.4)$ & $2 \cdot 30(0 \cdot 13)$ & $27.6(1.6)$ & $6.6(0.4)$ & $2 \cdot 17(0 \cdot 15)$ & $26 \cdot 0(1 \cdot 8)$ \\
\hline Thr & 3 & 12 & $7 \cdot 4(0 \cdot 3)$ & $2 \cdot 13(0 \cdot 12)$ & $25.5(1.4)$ & $6.8(0.4)$ & $1.93(0.13)$ & $23 \cdot 2(1 \cdot 6)$ \\
\hline Ala & 11 & 32 & $24.9(1 \cdot 1)$ & $2 \cdot 02(0 \cdot 10)$ & $24 \cdot 2(1 \cdot 2)$ & $22 \cdot 4(1 \cdot 3)$ & $1.80(0.12)$ & $21.6(1.4)$ \\
\hline Tyr & 2 & 2 & $4.0(0.2)$ & $1.92(0.09)$ & $23 \cdot 1(1 \cdot 0)$ & $3.7(0.2)$ & $1.74(0.10)$ & $20 \cdot 9(1.2)$ \\
\hline Val & 10 & 4 & $21 \cdot 5(0 \cdot 8)$ & $2 \cdot 12(0.08)$ & $25.4(0.9)$ & $20.0(1.2)$ & $1.96(0 \cdot 12)$ & $23.6(1.5)$ \\
\hline Ile & 8 & 7 & $16 \cdot 6(0 \cdot 7)$ & $2.00(0.09)$ & $24 \cdot 0(1 \cdot 1)$ & $14 \cdot 8(0 \cdot 7)$ & $1.78(0.09)$ & $21 \cdot 4(1 \cdot 1)$ \\
\hline Leu & 7 & 21 & $16 \cdot 0(0 \cdot 8)$ & $2.03(0.16)$ & $24.4(1.4)$ & $14.6(0.6)$ & $1.84(0.09)$ & $22.0(1.0)$ \\
\hline Phe & 0 & 12 & 1 & - & - & 1 & - & - \\
\hline
\end{tabular}

* Calculated from the amino acid sequence of GvpA.

$\uparrow$ Calculated from the amino acid sequence of GvpC.

$\$$ Amount of amino acid in the hydrolysate relative to the amount of Phe in the hydrolysate.

\$Amount of GvpA relative to the amount of Phe present in each sample calculated from the amino acid analyses. The method is explained by reference to the first example, Gly. (a) All Phe comes from GvpC. (b) GvpC contains 1 residue of Gly and 12 of Phe: therefore the amount of Gly in the hydrolysate contributed by GvpC is $1 / 12=0.083 \mathrm{~mol}$ Gly per mol Phe and the remainder $(6.977-0.083=6.894) \mathrm{mol}$ Gly per mol Phe is in GvpA. Calculations are based on original data; values shown are rounded to one decimal place. (c) Since there are 3 residues of Gly in GvpA it follows that the amount of GvpA present is (6.89 mol Gly per mol Phe)/(3 mol Gly per mol GvpA) $=2.30 \mathrm{~mol}$ GvpA per mol Phe.

$\|$ Ratio is mol GvpA divided by mol GvpC (1/12). For example: $2 \cdot 30 \mathrm{~mol} \mathrm{GvpA} /(1 / 12) \mathrm{mol} \mathrm{GvpC}=27 \cdot 6 \mathrm{~mol} \mathrm{GvpA}$ per mol GvpC.

$0.572 \mathrm{MPa}$ (Fig. 4). After removing the GvpC by rinsing four times in $6 \mathrm{M}$-urea and then dialysing, the $p_{\mathrm{c}}$ had fallen to $0.188 \mathrm{MPa}$ (Fig. 4). After resaturating the stripped gas vesicles with recombinant GvpC at $640 \mathrm{mg}$ $1^{-1}$ in $6 \mathrm{M}$-urea and then dialysing, the $p_{\mathrm{c}}$ had risen to $0.556 \mathrm{MPa}$, within $3 \%$ of the original value (Fig. 4). The gas vesicle preparations used in these measurements were the same preparations that were used in the determination of molar ratio of GvpA: GvpC (Table 2).

Experiments were performed to determine whether the GvpC from Anabaena would bind to the gas vesicles of two other cyanobacteria, Microcystis sp. and Aphanizomenon flos-aquae, that had been stripped of their native GvpCs. The same procedure was used in which the stripped gas vesicles were suspended in solutions of $6 \mathrm{M}$ urea containing recombinant Anabaena $\mathrm{GvpC}$ in various concentrations, from 0 to $640 \mu \mathrm{g} \mathrm{ml}^{-1}$, and then dialysed to remove the urea. The gas vesicles were rinsed four times to remove the solution containing unattached GvpC. Analysis by SDS-PAGE showed that each of the samples contained a band that corresponded in mobility with the Anabaena GvpC, which must have been attached to the rinsed gas vesicles.

The mean critical pressures of the gas vesicles isolated from both Microcystis sp. and Aphanizomenon decreased substantially when their GvpCs were removed, and were increased again when the recombinant Anabaena GvpC was attached (Table 3). As reported previously for Anabaena gas vesicles (Hayes et al., 1992), the critical pressure increased with increasing concentration of the recombinant GvpC supplied, but approached a maximum value at concentrations above $320 \mu \mathrm{g} \mathrm{ml}^{-1}$.

\section{Discussion}

\section{GvpC binds to all parts of the gas vesicle}

Our results indicate that the outer-surface protein, GvpC, is distributed over both the central cylinders and conical end caps of the gas vesicles isolated from Anabaena. The gas vesicles of cyanobacteria form by a gradual process of growth from biconical initials, which reach a certain size and then elongate by the extension of a cylindrical mid-section; it takes $12 \mathrm{~h}$ or more for the gas vesicle to reach its mature length (Waaland \& Branton, 1969; Lehmann \& Jost, 1971). In a population of growing cells the gas vesicles will be initiated continuously and those isolated at a given time will vary in age and length. We observed that both the short and long gas vesicles isolated from Anabaena became labelled by the antiGvpC antibodies (see Fig. $2 a$ ). This indicates that GvpC molecules are added to the surface of the gas vesicle as it grows.

We have demonstrated by antibody-labelling techniques that the recombinant $\mathrm{GvpC}$ became bound to 


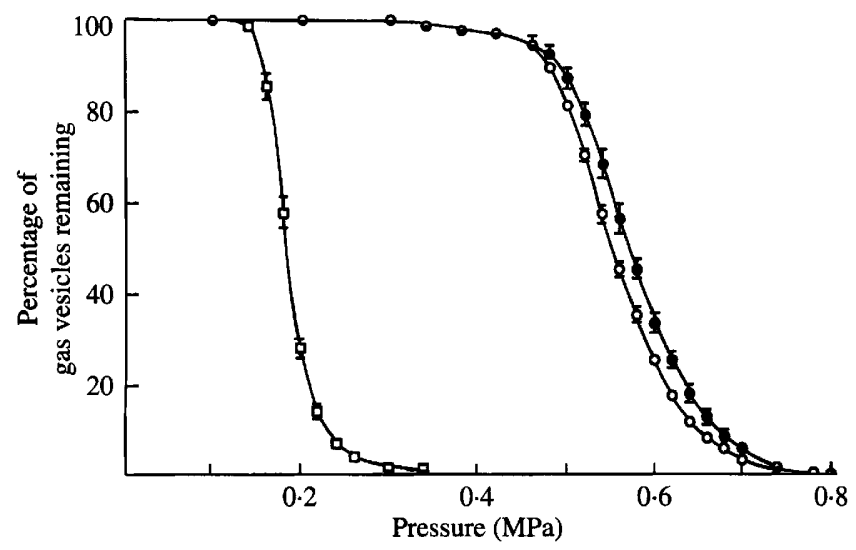

Fig. 4. Critical pressure distributions of Anabaena gas vesicles: vesicles containing the native $\mathrm{GvpC} ; \square$, gas vesicles stripped of their GvpC with $6 \mathrm{M}$-urea; $O$, stripped gas vesicles resaturated with recombinant GvpC.

both the cylinders and end caps of the isolated gas vesicles that had had their native GvpC removed by rinsing with urea. This indicates that $\mathrm{GvpC}$ will attach to all parts of the outer surface. In the cell GvpC would attach to new gas vesicle surfaces as they were formed by the assembly of GvpA. In this way the juvenile biconical gas vesicle would be stiffened as it grew. Without this stiffening the buckling pressure of the biconical gas vesicle would be less than the critical pressure of the GvpC-stiffened cylindrical gas vesicles, despite its smaller diameter (Walsby, 1991), and it might be collapsed by the combination of turgor pressure and hydrostatic pressure that impinged on it.

The observation that the amount of recombinant GvpC that binds to the gas vesicle is similar to the amount of native GvpC originally present suggests that the recombinant protein attaches to the same sites. The observation that over $97 \%$ of the original critical pressure is recovered when the recombinant GvpC binds to the stripped gas vesicles suggests that the recombinant protein confers the same properties and therefore rebinds in the same conformation as the native protein.

\section{The molecular interaction between GvpC and GvpA}

The observed ratio of GvpA:GvpC might be generated either by the way in which the GvpC molecules interact with the GvpA molecules or by some extraneous factor. The latter seems unlikely because a similar ratio is generated when the recombinant GvpC binds to the stripped gas vesicles in vitro. The molar ratio of 24.9:1 observed in isolated gas vesicles is close to $25: 1$. Since there are five similar 33-residue repeats in GvpC this suggests that each repeat interacts with five molecules of GvpA. The actual number of GvpAs associated with a repeating GvpC subunit might be lower if some of the GvpA sites had been unoccupied in the isolated gas vesicles. The slightly lower molar ratio of $22 \cdot 7: 1$ found in isolated gas vesicles that had been resaturated with recombinant GvpC may indicate that there had been some unoccupied sites on the native gas vesicles and that the actual number of GvpAs per GvpC repeat was only four. It is possible, however, that when the recombinant GvpC was allowed to bind to the stripped gas vesicles some overlapping of sites occurred, so that some of the five repeats in each GvpC were left unattached. Our results therefore support a model in which the number of GvpAs that are contacted by each of the five 33-residue repeats of $\mathrm{GvpC}$ is five, though they do not rule out the possibility that it is four.

Another factor that might affect the observed ratio of the two proteins is the difference between contact relationships of adjacent ribs in the central cylinders and end caps (Walsby, 1978). The antibody labelling indicates that GvpC is present in similar if not the same concentration in these different parts of the structure. If

Table 3. The effect on critical pressure of removing native GvpC from the gas vesicles of Anabaena flos-aquae, Aphanizomenon flos-aquae and Microcystis sp., and then replacing it with recombinant Anabaena GvpC

Numbers are means of at least three measurements (with standard deviations shown in parentheses).

\begin{tabular}{lccc}
\hline \hline & \multicolumn{3}{c}{ Critical pressure of gas vesicles (MPa) } \\
\cline { 2 - 4 } \multicolumn{1}{c}{ Species } & $\begin{array}{c}\text { Original, with } \\
\text { native GvpC }\end{array}$ & $\begin{array}{c}\text { Stripped of } \\
\text { GvpC }\end{array}$ & $\begin{array}{c}\text { Stripped and } \\
\text { saturated with } \\
\text { Anabaena } \text { GvpC* }\end{array}$ \\
\hline Anabaena flos-aquae & $0.572(0.006)$ & $0.188(0.002)$ & $0.556(0.004)$ \\
Aphanizomenon flos-aquae & $0.559(0.010) \dagger$ & $0.228(0.001)$ & $0.539(0.005)$ \\
Microcystis sp. & $0.760(0.007) \dagger$ & $0.261(0.001)$ & $0.663(0.001)$ \\
\hline \hline
\end{tabular}

* The value obtained at the highest concentration of GvpC used, $640 \mu \mathrm{g} \mathrm{ml}^{-1}$.

$\dagger$ The value obtained in turgorless cells. 
there are small differences, they may not perturb the ratio by much; it can be calculated from equations that describe the three-dimensional geometry of the gas vesicle (Walsby \& Armstrong, 1979) that in Anabaena gas vesicles of average length, the cylinders contain $85.6 \%$ of the wall material whereas the two end caps contain only $14.4 \%$.

We have considered ways in which molecules of GvpA and GvpC might fit together in the gas vesicle in such a way as to generate the ratio of five GvpA molecules to each 33-residue repeat. We assume that each 33-residue repeat must start and end at an equivalent position on a GvpA molecule; the repeating unit cell of the GvpC 33-residue repeat must therefore fit exactly over an integer number of unit cells of GvpA. We first discuss what is known of these unit cells.

The GvpA unit cell. Analysis of the gas vesicle structure by X-ray diffraction shows a unit cell formed by two layers of paired $\beta$-chains (Blaurock \& Walsby, 1976), whose volume corresponds with that of the GvpA molecule (Hayes et al., 1986). This crystallographic unit cell repeats at intervals $(i)$ of about $1.15 \mathrm{~nm}$ along the ribs, which have a width of $4.57 \mathrm{~nm}$ (Blaurock \& Walsby, 1976). The precise repeat should be given by $i=\left[(2 h)^{2}+(2 a)^{2}\right]^{1 / 2}$, in which $2 h$ is the dipeptide repeat, $0.69 \mathrm{~nm}$, and $a$ is the perpendicular distance between antiparallel $\beta$-chains, $0.472 \mathrm{~nm}$ (see Walsby \& Hayes, 1989); hence $i=1.17 \mathrm{~nm}$. The centres of the nearest GvpA molecules in adjacent ribs form an angle of $86^{\circ}$ to the rib axis, and the edges of the molecules are therefore staggered by $0.68 \mathrm{~nm}$ at the rib junctions (Fig. 5).

The unit cell of the 33-residue repeat in GvpC. There is no direct information on the crystallographic structure of GvpC but secondary-structure predictions have been made using the Wisconsin package of programs (Devereux et al., 1984). The 33-residue repeats were suggested to be mainly in the form of $\alpha$-helix, though it is possible that three of the residues (Gln-Phe-Leu) may be in random coil or even $\beta$-chain. The minimum length of each 33-residue repeat, when all residues are in a continuous $\alpha$-helix, is $33 \times 0.15 \mathrm{~nm}=4.95 \mathrm{~nm}$, and the maximum length, when three of the residues are in a $\beta$-chain, is $4.50 \mathrm{~nm}+3 \times 0.345 \mathrm{~nm}=5.54 \mathrm{~nm}$.

Fig. 5 shows three ways in which the $\alpha$-helical repeats of GvpC might be arranged.

(a) Along the rib. If the 33-residue repeats of GvpC were to run parallel to the rib axis (Fig. $5 a$ ) each could span four GvpA molecules (minimum length $4.68 \mathrm{~nm}$ ) but would not be quite long enough to contact five GvpAs (minimum length $5.85 \mathrm{~nm}$ ).

(b) Across the rib, parallel to the $\beta$-chains in GvpA. In a number of proteins $\alpha$-helices lie in the grooves between the antiparallel chains of $\beta$-sheet (Schulz \& Schirmer,
1979); the 33-residue repeats of GvpC might run between the $\beta$-chains of GvpA. Because the GvpA residues in adjacent ribs are staggered (Blaurock \& Walsby, 1976), the grooves would not be aligned with one another (see Fig. $5 b$ ). The $\alpha$-helical parts of the repeats could not therefore run across the junction of adjacent ribs. There would have to be some random coil to span this stagger. The overall length of the repeat shown in Fig. $5(b)$ is calculated to be $4.50 \mathrm{~nm}+0.94 \mathrm{~nm}=5.44 \mathrm{~nm}$, which is within the maximum value given above. Each of the 33-residue repeats of $\mathrm{GvpC}$ would contact the equivalent of only two complete molecules of GvpA.

(c) Across the rib, and across the $\beta$-chains in GvpA. If the $\alpha$-helical 33-residue repeats of GvpC were to slope in the opposite direction to the $\beta$-chains of GvpA it is calculated that each repeat would cross at an angle of $\phi=23.8^{\circ}$ to the rib axis, and the distance across the rib in this orientation would be $5.00 \mathrm{~nm}$. The $\alpha$-helical region of the molecule could overlap the rib junction. In this arrangement each 33-residue repeat would contact five molecules of GvpA.

This third arrangement has two features that recommend it: (1) the five repeats would together contact 25 molecules of GvpA, which corresponds with the observed ratio; (2) the $\alpha$-helical regions of the GvpC lie across the rib junction, where they might provide the stiffening that is thought to postpone the buckling of the gas vesicle (Walsby, 1991). These features are lacking in the other two arrangements. Direct evidence is needed of the actual arrangment, but this discussion is intended to focus attention on the ways in which the two proteins might interact. There are, in addition, a number of other constraints that will need to be considered. (1) It might be necessary for the $\mathrm{N}$ - or C-terminal sequences of $\mathrm{GvpC}$ to act as spacers holding the rods of GvpC five GvpA molecules apart. (2) Each 33-residue repeat should be oriented with similar or homologous residues facing in the same direction. In a continuous $\alpha$-helix the side chains 33 residues apart would be oriented at $60^{\circ}$ to one another; one or more residues in other conformations may be required to allow the successive repeats to twist into the same orientation.

Our model might also be generally applicable to the interaction between GvpA and GvpC in other organisms. All gas-vacuolate cyanobacteria investigated have GvpAs of highly homologous sequence and those sequenced in entirety are of similar size, 70 or 71 residues (see Walker et al., 1984; Hayes et al., 1986; Tandeau de Marsac et al., 1985; Damerval et al., 1991). The GvpCs, however, vary somewhat in size (Griffiths et al., 1992); for example, GvpC from Calothrix sp., which has an $M_{\mathrm{r}}$ of only 19179, has only four 33-residue repeats (Damerval et al., 1987). Each molecule would therefore span only four ribs and a GvpA: GvpC molar ratio of 20 would be expected. 


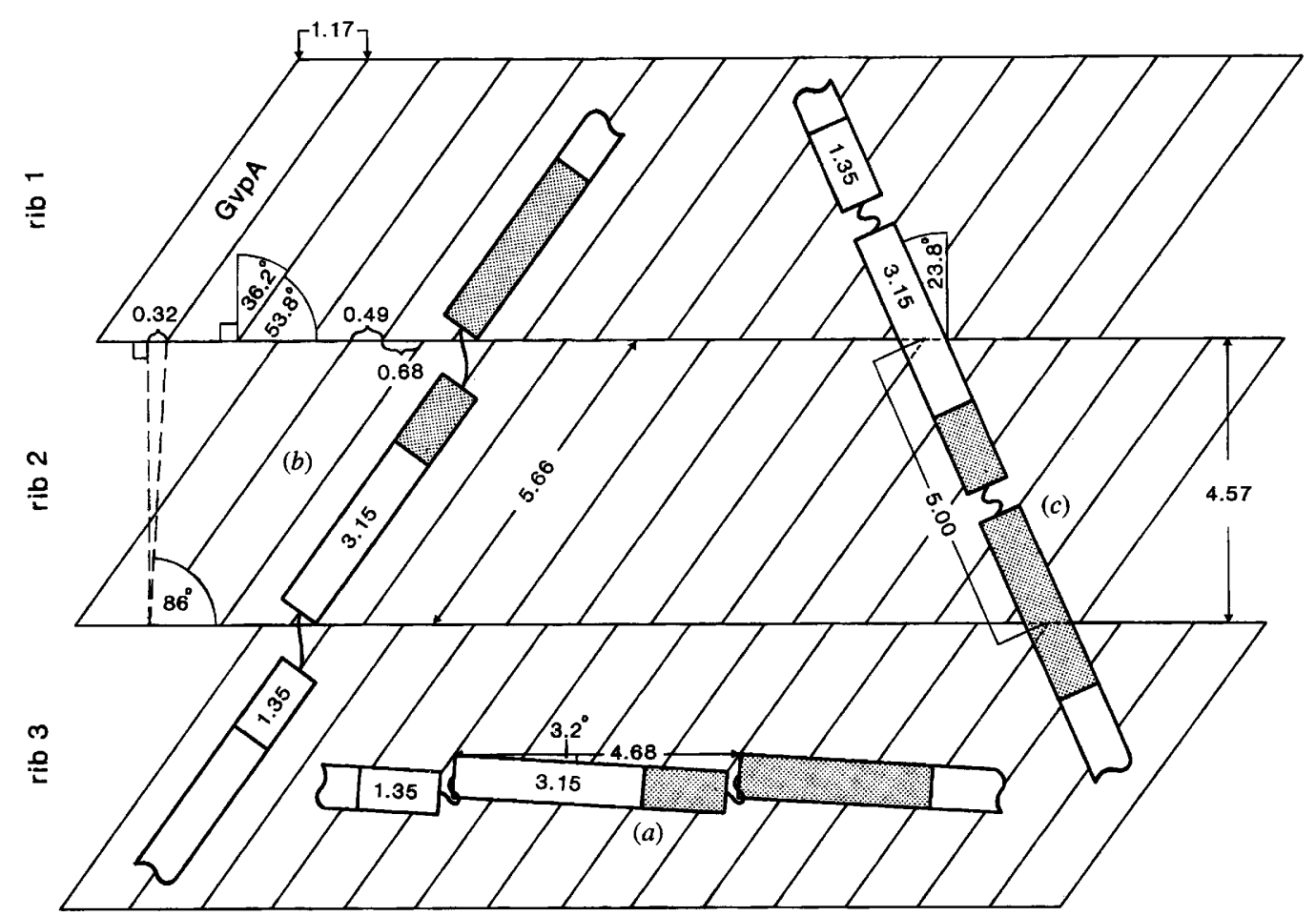

Fig. 5. A diagram of three possible ways in which the 33-residue repeats of $\mathrm{GvpC}$ might form periodic interactions with the molecules of GvpA, depicted as 1.17-nm-wide parallelogram tiles that form the 4.57-nm-wide ribs in the cylindrical part of the gas vesicle. The GvpA molecules in adjacent ribs are staggered by $0.32 \mathrm{~nm}$, and the grooves between them are offset by $0.68 \mathrm{~nm}$ at the rib junctions. Each GvpC repeat is predicted to be made of two $\alpha$-helices of length $1.35 \mathrm{~nm}$ ( 9 residues) and $3.15 \mathrm{~nm}$ ( 21 residues) joined by three residues of random coil, length $<1.04 \mathrm{~nm}$. The GvpC helices may be oriented in one of three ways: two complete 33-residue repeats (one shaded) are shown in each case. (a) Along the rib, repeating at intervals of four GvpAs; they may be present at the edge rather than the middle of the rib. (b) Across the ribs, parallel to the $\beta$-chain in GvpA. (c) Across the ribs, crossing five GvpA molecules. All measurements are in $\mathrm{nm}$.

The N-terminal sequence of Anabaena GvpC shows many differences from that of GvpC in other cyanobacteria (Damerval et al., 1987; Griffiths et al., 1992). Nevertheless, we have shown that the recombinant Anabaena protein will both bind to and restrengthen gas vesicles of some other species. This suggests that there is some considerable latitude in the sequence of a functional GvpC. It may be significant that the recombinant Anabaena GvpC almost completely restores the strength of the Aphanizomenon gas vesicle, whose GvpA has an identical N-terminal sequence to that of Anabaena GvpA, but only partially restores the strength of the Microcystis gas vesicle, whose GvpA differs in a few residues (Griffiths et al., 1992).

In halobacteria the GvpAs, though also homologous, are larger, 76-78 residues (Surek et al., 1988; Englert et al., 1990; Horne et al., 1988; Jones et al., 1991). The dimensions of the repeating unit cell have not been fully determined (but see Blaurock \& Wober, 1976). There is a gene $(g v p C)$ product that shows some homology to cyanobacterial GvpC (Horne et al., 1991; Jones et al., 1991) but it is much larger and has seven partially conserved repeats that vary in size from 31 to 41 residues and a much larger non-repeating C-terminal domain. It may be expected that this molecule would have a similar function to GvpC in cyanobacterial gas vesicles, but the interactions between the proteins may differ in a number of details.

We are grateful to $\mathrm{Mr} \mathbf{R}$. Porter for assistance with electron microscopy and $\mathrm{Mr} \mathrm{T}$. Colburn for drawing and preparation of the figures. Amino acid analysis was performed by $\mathrm{Dr}$ W. Mawby of the Molecular Recognition Unit, and by Dr K. J. Flynn of the University of Swansea. This work was supported by a grant from the SERC.

\section{References}

Armstrong, R. E., Hayes, P. K. \& Walsby, A. E. (1983). Gas vacuole formation in hormogonia of Nostoc muscorum. Journal of General Microbiology 128, 263-170.

Blaurock, A. E. \& Walsby, A. E. (1976). Crystalline structure of the gas vesicle wall from Anabaena flos-aquae. Journal of Molecular Biology 105, 183-199.

BLAUROCK, A. E. \& WOBER, W. (1976). Structure of the wall of Halobacterium halobium gas vesicles. Journal of Molecular Biology 106, 871-888.

Bowen, C. C. \& JENSEN, T. E. (1965). Blue-green algae: fine structure of the gas vacuoles. Science 147, 1460-1462.

Damerval, T., Houmard, J., Guglielmi, G., Csiszàr, K. \& Tandeau DE MARSAC, N. (1987). A developmentally regulated gvp $A B C$ operon 
is involved in the formation of gas vesicles in the cyanobacterium Calothrix 7601. Gene 54, 83-92.

Damerval, T., Castets, A.-M., Guglielmi, G., Houmard, J. \& TANDEAU DE MARSAC, N. (1989). Occurrence and distribution of gas vesicle genes among cyanobacteria. Journal of Bacteriology 171, $1445-1452$.

Damerval, T., Castets, A.-M., Houmard, J. \& Tandeau de Marsac, N. (1991). Gas vesicle synthesis in the cyanobacterium Pseudanabaena sp.: occurrence of a single photoregulated gene. Molecular Microbiology 5, 657-664.

DeVEReuX, J., Haeberli, P. \& Smithies, O. (1984). A comprehensive set of sequence analysis programs for the VAX. Nucleic Acids Research 12, 387-395.

Englert, C., HoRne, M. \& Pfeifer, F. (1990). Expression of the major gas vesicle protein gene in the halophilic archaebacterium Haloferax mediterranei is modulated by salt. Molecular and General Genetics 222, 225-232.

FLYNN, K. J. (1988). Some practical aspects of the analysis of dissolved free amino acids in natural waters and within microalgae by the use of HPLC. Chemical Ecology 3, 269-293.

Griffiths, A. E., Walsby, A. E. \& Hayes, P. K. (1992). The homologies of gas vesicle proteins. Journal of General Microbiology 138, 1243-1250.

Harlow, E. \& LANE, D. (1988). Antibodies. Cold Spring Harbor, NY: Cold Spring Harbor Laboratory.

Hayat, M. A. (1989). Principles and Techniques of Electron Microscopy. London: Macmillan.

HaYEs, P. K. \& WalsBY, A. E. (1986). The inverse correlation between width and strength of gas vesicles in cyanobacteria. British Phycological Journal 21, 191-197.

Hayes, P. K., Walsby, A. E. \& Walker, J. E. (1986). Complete amino acid sequence of cyanobacterial gas-vesicle protein indicates a 70 residue molecule that corresponds in size to the crystallographic unit cell. Biochemical Journal 236, 31-36.

Hayes, P. K., Lazarus, C. M., Bees, A., Walker, J. E. \& Walsby, A. E. (1988). The protein encoded by $g v p C$ is a minor component of gas vesicles isolated from the cyanobacteria Anabaena flos-aquae and Microcystis sp. Molecular Microbiology 2, 545-552.

HAYES, P. K., BuchHOLZ, B. \& WaLSBY, A. E. (1992). Gas vesicles are strengthened by the outer-surface protein, GvpC. Archives of Microbiology 157, 229-234.

Horne, M., Englert, C. \& PFeifer, F. (1988). Two genes encoding gas vacuole proteins in Halobacterium halobium. Molecular and General Genetics 213, 459-464.

Horne, M., Englert, C., Wimmer, C. \& Pfeifer, F. (1991). A DNA region of $9 \mathrm{kbp}$ contains all genes necessary for gas vesicle synthesis in halophilic archaebacteria. Molecular Microbiology 5, 1159-1174.

Jones, J. G., Young, D. C. \& DasSarma, S. (1991). Structure and organization of the gas vesicle gene cluster on the Halobacterium halobium plasmid pNCR100. Gene 102, 1017-1022.

Jost, M. (1965). Die Ultrastruktur von Oscillatoria rubescens D.C. Archiv für Mikrobiologie 50, 211-245.

Jost, M. \& JoneS, D. D. (1970). Morphological parameters and macromolecular organization of gas vacuole membranes of Microcystis aeruginosa Kuetz. emend. Elenkin. Canadian Journal of Microbiology 16, 159-164.

LAEMMLI, U. K. (1970). Cleavage of structural proteins during the assembly of the head of bacteriophage T4. Nature, London 227, 680-685.
LehmanN, H. \& Jost, M. (1971). Kinetics of the assembly of gas vacuoles in the blue-green alga Microcystis aeruginosa Kuetz. emend. Elekin. Archiv für Microbiologie 79, 59-68.

Powell, R. S., Walsby, A. E., Hayes, P. K. \& Porter, R. (1991). Antibodies to the N-terminal sequence of GVPa bind to the ends of gas vesicles. Journal of General Microbiology 137, 2395-2400.

RippKa, R., Deruelles, J., Waterbury, J. B., Herdman, M. \& STANIER, R. Y. (1979). Generic assignments, strain histories and properties of pure cultures of cyanobacteria. Journal of General Microbiology 111, 1-61.

Schulz, G. E. \& SchiRmer, R. H. (1979). Principles of Protein Structure. New York: Springer-Verlag.

Surek, B., Pillay, B., Rdest, U., Beyreuther, K. \& Goebel, W. (1988). Evidence for two different gas vesicle proteins and genes in Halobacterium halobium. Journal of Bacteriology 70, 1746-1751.

TANDEAU DE MARSAC, N. \& Houmard, J. (1993). Adaptation of cyanobacteria to environmental stimuli: new steps towards molecular mechanisms. FEMS Microbiology Reviews 104, 119-189.

Tandeau de Marsac, N., Mazel, D., Bryant, D. A. \& Houmard, J. (1985). Molecular cloning and nucleotide sequence of a developmentally regulated gene from the cyanobacterium Calothrix PCC 7601: a gas vesicle protein gene. Nucleic Acids Research 13, 72237236.

THOMPSON, E. O. P. \& SANGER, F. (1963). Halogenation of tyrosine during acid hydrolysis. Biochimica et Biophysica Acta 71, 468-471.

WAALAND, J. R. \& BRANTON, D. (1969). Gas vacuole development in a blue-green alga. Science 163, 1339-1341.

WALKER, J. E. \& WALSBY, A. E. (1983). Molecular weight of gas-vesicle protein from the planktonic cyanobacterium Anabaena flos-aquae and implications for structure of the vesicle. Biochemical Journal 209, 809-815.

WalkeR, J. E., Hayes, P. K. \& Walsby, A. E. (1984). Homology of gas vesicle proteins in cyanobacteria and halobacteria. Journal of General Microbiology 130, 2709-2715.

WALSBY, A. E. (1971). The pressure relationships of gas vacuoles. Proceedings of the Royal Society of London B178, 301-326.

WALSBY, A. E. (1972). Structure and function of gas vacuoles. Bacteriological Reviews 36, 1-32.

WALSBY, A. E. (1977). Absence of gas vesicle protein in a mutant of Anabaena flos-aquae. Archives of Microbiology 114, 167-170.

WALSBY, A. E. (1978). The gas vesicles of aquatic prokaryotes. In Relations between Structure and Function in the Prokaryotic Cell (Symposia of the Society for General Microbiology no. 28), pp. 327-358. Edited by R. Y. Stanier, H. J. Rogers \& J. B. Ward. Cambridge: Cambridge University Press.

WALSBY, A. E. (1980). The water relations of gas-vacuolate prokaryotes. Proceedings of the Royal Society of London B208, 73-102.

WALSBY, A. E. (1991). The mechanical properties of the Microcystis gas vesicle. Journal of General Microbiology 137, 2401-2408.

WALSBY, A. E. \& ARMSTRONG, R. E. (1979). Average thickness of the gas vesicle wall. Journal of Molecular Biology 129, 279-285.

WalsBy, A. E. \& BleYthing, A. (1988). The dimensions of cyanobacterial gas vesicles in relation to their efficiency in providing buoyancy and withstanding pressure. Journal of General Microbiology 134, 2635-2645.

WALSBY, A. E. \& HAYES, P. K. (1988). The minor cyanobacterial gas vesicle protein, GVPc, is attached to the outer surface of the gas vesicle. Journal of General Microbiology 134, 2647-2657.

WALSBY, A. E. \& HAYES, P. K. (1989). Gas vesicle proteins. Biochemical Journal 264, 313-322. 